\title{
The Effect of Academic Self-Efficacy and Mindfulness on Students Academic Stress During the Covid-19 Pandemic Period
}

\author{
Teguh Lesmana ${ }^{1 *}$ Lulun Bidangan $^{1}$ \\ ${ }^{1}$ Psychology Study Program, Bunda Mulia University, Faculty of Social Sciences and Humanities, Jakarta, 14430, \\ Indonesia \\ *Corresponding author. Email: teguhlesmana73@gmail.com
}

\begin{abstract}
This study aims to determine the effect of academic self-efficacy and mindfulness towards academic stress on college students who have experience online learning during the Covid-19 pandemic. The research method used is quantitative research methods with correlation techniques. The number of samples in this study were 191 respondents who were selected using purposive sampling technique. The measuring instrument used is the College Academic Self-Efficacy Scale (CASES) to measure self-compassion, Five Facet Mindfulness Questionnaires-Short Form (FFMQ-SF) to measure mindfulness and Perceived Stress Inventory for Academic Stress (PSI) to measure academic stress. The results showed that there was a negative relationship between academic self-efficacy and mindfulness towards academic stress. The results of the negative relationship between academic self-efficacy and mindfulness towards academic stress support the findings of previous studies, so that students who have experienced online learning during the Covid-19 pandemic and began to experience stress because of this can try to apply mindful thoughts. In addition, besides mindful thoughts, they need also to have faith in their academic ability during online learning so they can have more positive though and not being vulnerable to stress.
\end{abstract}

Keywords: academic self-efficacy, mindfulness, academic stress

\section{INTRODUCTION}

The corona virus outbreak has spread to a number of countries in the world, including Indonesia. According to Nuraini [17], initially the corona virus could enter Indonesia through two patients, one of whom was a dance teacher and made physical contact with a Japanese foreigner who was positively infected with the corona virus. Since the confirmation of the first case of the corona virus in Indonesia on March 2, 2020 [8], there has been an increase in cases from time to time until October 9, 2020, there have been 328,952 positive cases of the corona virus reported [9]. According to Prasetyo [19], the way that can be done to break the chain of spreading corona is by implementing physical distancing and independent isolation. However, keeping a long distance, according to research conducted by researchers at the Faculty of Medicine, Padjadjaran University, Bandung [3] can trigger depression and based on the assessment conducted, it was found that $47 \%$ of students experienced depression as a result of the Covid-19 pandemic.

According to Mahardika [13] there are several reasons for students to experience anxiety during the Covid-19 pandemic, one of which is due to the condition of the study where deadlines, online college assignments that accumulate become more pressure on students. Based on interviews conducted with psychologists [1], it is known that the cause of students experiencing anxiety and stress when studying online during the pandemic is not being able to adapt quickly so that students start to feel anxious and stressed about the load of online college assignments. The inability to adapt to online college learning styles can be related to the lack of academic self-efficacy possessed by students. Bandura [18] explains that academic selfefficacy is students' confidence in their ability to succeed in assignments, lessons or academic activities.

Based on previous research [14], it was found that there was a significant relationship between academic selfefficacy and academic stress where the relationship was negative, namely the higher the academic self-efficacy, the lower the academic stress. Stress due to students' lack of confidence in their ability to complete assignments or academic activities can be a problem during the Covid-19 pandemic. However, other factors that can also trigger stress in students are excessive worry and anxiety about uncertainty in life during the new normal period [20]. This excessive worry can indicate that students lack mindfulness.

By applying a state of mindfulness in everyday life, the stress that may be experienced will be better managed. 
Based on the results of experimental research, it was found that mindfulness exercise was proven to reduce stress [2]. Mindfulness is described by Naik et al. [16] as a condition that has three key characteristics, namely: (1) having a purpose, (2) being fully present, and (3) acceptance. Having a goal means that when you are in a state of mindfulness, a person is deliberately and aimed at directing his attention to one thing rather than directing his attention to various things. Fully present means that when in a state of mindfulness, a person only focuses his mind and attention on an activity and does not think too much about what has happened or what has not happened. Acceptance means that mindfulness involves a person not to have an assessment of whatever happens in his life, be it a negative or positive assessment, so that the events that occur are only accepted as part of life. Some research results also show that mindfulness has techniques that can be applied to deal with stress in everyday life [12].

This research was conducted to better understand the psychological impact experienced by students studying online during the COVID-19 pandemic, in which students when studying online at home must quickly adapt to the demands of many online college assignments. The number of tasks students have to do can affect stress levels when studying online and lead to depression. On the other hand, studying online at home is the only option to maintain health and avoid the COVID-19 virus outbreak. Thus, this research is also to broaden the horizons and research in the issues of educational psychology and positive psychology. Based on the background of the problems above, the problem formulations to be discussed in this study are as follows;

"Can mindfulness affected student stress levels during the covid-19 pandemic time?"

"Can academic self-efficacy affected student stress levels during the covid-19 pandemic time?"

In this study, there are 2 hypotheses, as follows;

H1: Mindfulness has significant effect on student's academic stress during the covid-19 pandemic time.

$\mathrm{H} 2$ : Academic self-efficacy has a significant effect on student's academic stress during the covid-19 pandemic time.

\section{METHOD}

\subsection{Design}

The research design used was non-experimental design and this research is a quantitative study using a questionnaire to obtain research data. The sampling technique used was purposive sampling with participant criteria: active students who studied in Jakarta without restricted by gender and had undergone online learning during the Covid-19 pandemic. This research is a correlation study with correlation analysis techniques using the SPSS program to find the correlation value of the 3 variables to be measured.

\subsection{Participant}

Participants in this study consisted of 191 active students who studied in Jakarta and had undergone online learning during the Covid-19 pandemic.

\subsection{Instrument}

The instrument that researchers use to measure the Stress level variable is the Perceived Stress Inventory (PSI). This scale originally belongs to Avdija [4] and has been adapted into Indonesian by researcher. This measuring tool consists of 13 statement items which assess academic stressor, where all the items are favorable statements. The scale contained in it is also a Likert scale with 10 alternative answers. A scale score of 1 indicates "no stress" while a scale score of 10 indicates "high stress".

The instruments that the researchers used to measure the academic self-efficacy variable were the College Academic Self-Efficacy Scale (CASES). For this CASES measurement tool, the reference journal taken by the researcher is a research journal conducted by Ifdil et al. [11]. This measuring tool consists of 33 statement items, where the items are a favorable statement. The scale contained in it is also a Likert scale with 5 alternative answers. A scale score of 1 indicates "Strongly Disagree" while a scale score of 5 indicates "Strongly Agree".

In this study to measure mindfulness, Gu et al's Five Facet Mindfulness Questionnaires short form (FFMQ-SF) was used. (2016) which has been adapted into Indonesian by the author. Gu, et al. [10] is a measuring tool that measures mindfulness on the same theoretical basis as the original measuring instrument [5], but the number of questionnaire items is less, consisting of only 15 statements, where the original questionnaire was. consists of 39 statement items. The scale contained in it is also a Likert scale with 5 alternative answers. A scale score of 1 indicates "Strongly Disagree" while a scale score of 5 indicates "Strongly Agree". To obtain full score of mindfulness, the combined sum of all the facet can contribute to overall score of mindfulness.

The reliability test of measuring instruments on the participant of research conducted on 36 respondents (pilot study) and 86 respondents in total (field study). Where there are 3 measuring instruments, namely Perceived Stress Inventory (PSI), College Academic Self-Efficacy Scale (CASES) and Five Facet Mindfulness Questionnaires short form (FFMQ-SF). PSI and CASES have a good cronbach alpha in pilot and field study, while FFMQ-SF has 3 dimensions which cannot be used according to pilot study because of low cronbach alpha so only 2 dimensions remain from mindfulness in FFMQ-SF to be used in field study, which is as follows: 
Table 1 Reliability of measurement

\begin{tabular}{|c|c|c|}
\hline & Pilot & Field \\
\hline PSI & 0.893 & 0.900 \\
\hline CASES & 0.934 & 0.947 \\
\hline Mindfulness (5 facet) & & \\
Observing & 0.546 & - \\
Desribing & 0.553 & - \\
Acting With Aware & 0.620 & 0.640 \\
Nonjudging & 0.640 & 0.666 \\
Nonreactivity & 0.586 & - \\
\hline
\end{tabular}

\subsection{Procedure}

The research will be conducted in the Jakarta area, namely for active students who had undergone online learning during the Covid-19 pandemic. In addition, researchers will distribute questionnaires online with the consideration of efficient use of time and the quantity of data obtained is quite a lot in a short time.

\subsection{Data Analysis Technique}

The data analysis technique used is to use the SPSS version 21 program to calculate the test results of measuring instruments and calculate the levels of PSI, CASES and FFMQ-SF. The method used to calculate the test results of the measuring instrument is the reliability analysis and looking at Cronbach alpha to determine the level of reliability of the measuring instrument, while eliminating items that do not pass the test by looking at the corrected item total correlation value in the SPSS program. After obtaining research participants, the method used to analyze the relationship between PSI, CASES and FFMQ$\mathrm{SF}$ was to use the Pearson correlation analysis technique for normally distributed data, while Spearman's correlation analysis was used for abnormally distributed data.

\section{RESULT}

Based on data collection that has been done by researchers, it was obtained 191 participants who were willing to become research subjects. The following is an illustration of the demographic data of participants who are willing to be the subject. Below is some information, namely the gender and age of the participants, which are spread over the age range of 18-25 years, the area of residence.

Table 2 Demographic description of research respondents

\begin{tabular}{|l|l|l|}
\hline Demographic & Frequency & Percentage \\
\hline Gender & & \\
Male & 74 & 39.2 \\
Female & 115 & 60.8 \\
\hline Age & & \\
$18-20$ & 92 & 48.7 \\
$21-23$ & 85 & 45.1 \\
$24-25$ & 12 & 6.2 \\
\hline Area & & \\
\hline
\end{tabular}

\begin{tabular}{|l|l|l|}
\hline Central Jakarta & 27 & 14.3 \\
East Jakarta & 5 & 2.6 \\
South Jakarta & 10 & 5.3 \\
west Jakarta & 19 & 10.1 \\
North Jakarta & 128 & 67.7 \\
\hline
\end{tabular}

In this study, researchers conducted a normality test using the one-sample Kolmogorov-Smirnov test. The academic self-efficacy, all stress dimension and mindfulness are not distributed normally. The three variable all had value below the significance value of $0.05(\mathrm{p}<0.05)$.

The results showed that there was a significant negative relationship between academic self-efficacy and the level of academic stress ( $\left.r=-0.158^{*}, \mathrm{p}=0.029\right)$, and mindfulness also had a significant negative relationship with academic stress levels $\left(r=-0.372^{* *}, p=0.000\right)$. So it can be interpreted that the higher a person's academic selfefficacy and mindfulness, the lower the level of academic stress of that individual. Vice versa, the lower an individual's academic self-effiacy and mindfulness, it could indicate higher level of stress.

Table 3 Variable correlation results

\begin{tabular}{|l|l|l|}
\hline Variable & $\begin{array}{l}\text { Correlation } \\
\text { coefficient }\end{array}$ & $\begin{array}{l}\text { Sig (2- } \\
\text { tailed) }\end{array}$ \\
\hline $\begin{array}{l}\text { Academic self-efficacy } \\
\text { and academic stress }\end{array}$ & $-0.158^{*}$ & 0.029 \\
\hline $\begin{array}{l}\text { Mindfulness and academic } \\
\text { stress }\end{array}$ & $-0.372^{* *}$ & 0.000 \\
\hline
\end{tabular}

\section{DISCUSSION}

This study aims to examine the relationship between academic self-efficacy and mindfulness towards academic stress. Based on the research that has been done, the results of the correlation test indicate that there is a low negative relationship/correlation between academic selfefficacy and mindfulness towards academic stress. Researchers specifically examined the relationship between these three variables for active students who studied in Jakarta and had undergone online learning during the Covid-19 pandemic. Previous research conducted in South Africa [14] found a low to moderate negative relationship between academic self-efficacy and academic stress. This means that these findings are in line with what researchers have done, that the higher a person's academic self-efficacy, the lower the academic stress of the individual, where the academic stress condition assumed by researchers here is that the condition of online learning during covid-19 pandemic. Meanwhile it was also found by previous research [6] that mindfulness have significant role in reducing academic stress through attention regulation and focus which in turn can make students cope with their stress. Thus the findings of previous studies also support the results of research conducted by researchers and mindfulness has indeed been 
shown to have a significant relationship with academic stress.

There are several other previous studies that also harmonize and support the research results obtained by researchers. Brausch [7] state that there is a negative correlation between mindfulness and self-efficacy towards academic stress in college students, which means that the higher mindfulness will affect the lower academic stress or vice versa. In addition, the results of research conducted by Mulyadi, Rahardjo and Basuki [15] show that academic self-efficacy have effect towards academic stress among children participating in homeschooling activities where the role of parent-child relationship and self-esteem may also have direct and indirect effect towards academic stress. They also stated that there is a negative relationship between academic self-efficacy and academic stress in a negative direction. With confidence in their academic abilities, as well as mindful focus and attention, students can cope with stress that may be experienced during online learning activities during the Covid-19 pandemic.

\section{CONCLUSION}

Based on the results of the correlation test in the discussion of this study, it can be concluded that the variable academic self-efficacy and mindfulness has a significant relationship towards academic stress on students during pandemic covid-19 so that both research hypothesis (H1 \& H2) is accepted. This can be seen from the existence of a significant negative correlation between academic self-efficacy and mindfulness towards academic stress. Where this indicates that the higher the individual's academic self-efficacy and mindfulness, the lower the academic stress value shown by the individual and vice versa.

Suggestions for further research, it is suggested to pay more attention to respondents in terms of the characteristics they are looking for and the number of respondents so that they get more balanced and more generalizable results. In addition, further research is also recommended to use sources or theoretical references with a distance of publication time that is close to the time of writing the next research. This is to minimize the lack of relevance of these references to current conditions, given the rapid development of the times.

Practical advice from looking at the results of the study which states that individuals with academic self-efficacy and mindfulness variables have a significant relationship with this variable of academic stress. Researchers suggest that college students who have experienced stress during pandemic covid-19 to develop mindfulness mind set in themselves so that they can live life optimally during the pandemic. They also have to have faith in their academic ability because without those faith, they will more vulnerable to stress during the covid-19 pandemic. If students can develop their mindfulness and academic selfefficacy, they will be more accepting of all the circumstances of his life. This is very important to do so that the students can live their life more optimally and be able to survive when they experience life difficulties.

\section{REFERENCES}

[1] Ajeng, A., \& Hanifah, W. (2020). Kuliah daring dan kesehatan mental. Retrieved from: http:// linikampus.com/2020/05/06/kuliah-daring-dankesehatan-mental-2/

[2] Alem, Y., Behrendt, H., Belot, M., Biro, A. (2018). Mindfulness and stress - a randomized experiment. Working Papers in Economics No. 725: Department of Economics. Retrieved from: https:/gupea.ub.gu.se/ bitstream/2077/55812/1/gupea_2077_55812_1.pdf

[3] Anastasia, T. (2020). 47 Persen Mahasiswa di Indonesia Alami Gejala Depresi Akibat COVID-19. Retrieved from: https://www.klikdokter.com/infosehat/read/3638747/47-persen-mahasiswa-di-indonesiaalami-gejala-depresi-akibat-covid-19

[4] Avdija, A. S. (2018). College stress: Testing the unidimensionality of a standardized stress measuring inventory designed to assess stress among college students. Children and Teenagers, 1(2): 68-83. DOI: 10.22158/ct.v1n2p68

[5] Baer, R. A., Smith, G. T., Hopkins, J., Krietemeyer, J., \& Toney, L. (2006). Using self-report assessment methods to explore facets of mindfulness. Assessment, 13(1): 27-45. DOI: 10.1177/1073191105283504 (C) 2006 by Sage Publications.

[6] Blackburn, T. (2020). The relationship between mindfulness, academic stress, and attention. All Graduate Theses and Dissertations. 7940. Retrieved from https://digitalcommons.usu.edu/etd/7940

[7] Brausch, B. D. (2011). The role of mindfulness in academic stress, self-efficacy, and achievement in college students. Masters Theses. 147. https://thekeep .eiu.edu/theses/147

[8] Debora, Y. (2020). Riwayat kasus corona di Indonesia, dari Maret hingga September 2020. Retrieved from https://tirto.id/riwayat-kasus-corona-diindonesia-dari-maret-hingga-september-2020-f4d6

[9] Flora, M. (2020). Update corona 10 oktober: bertambah 4.294, total kasus positif covid-19 di Indonesia jadi 328.952. Retrieved from https://www. liputan6.com/news/read/4378769/update-corona-10oktober-bertambah-4294-total-kasus-positif-covid-19di-indonesia-jadi-328952 
[10] Gu, J., Strauss, C., Crane, C., Barnhofer, T., Karl, A., Cavanagh, K., \& Kuyken, W. (2016). Examining the factor structure of the 39-item and 15-item versions of the five facet mindfulness questionnaire before and after mindfulness-based cognitive therapy for people with recurrent depression. Psychological assessment, 28(7), 791-802. doi: 10.1037/pas0000263

[11] Ifdil, I., Bariyyah, K., Dewi, A. K., \& Rangka, I. B. (2019). The college academic self-efficacy scale (CASES); An Indonesian validation to measure the selfefficacy of students. Jurnal Kajian Bimbingan dan Konseling, 4(4): 115-121. DOI: 10.17977/ um001v4i42019p115

[12] Jansen, M., Heerkens, Y., Kuijer, W., Heijden, B. V. D., \& Engels, J. (2018). Effects of mindfulnessbased stress reduction on employess mental health: A systematic review. Plos One, 13(1): e0191332. Retrieved from https://doi.org/10.1371/journal.pone. 0191332

[13] Mahardika, A. (2020). 7 penyebab gangguan kecemasan mahasiswa di tengah pandemi corona. Retrieved from https://health.detik.com/beritadetikhealth/d-4980442/7-penyebab-gangguan-

kecemasan-mahasiswa-di-tengah-pandemi-corona

[14] Matoti, S. N., \& Lekhu, M. A. (2019). Academic stress and academic self-efficacy of first year preservice teachers. Proceedings of SOCIOINT 2019-6th International Conference on Education, Social Sciences and Humanities. Retrieved from https://pdfs. semanticscholar.org/f318/1dbd3c91ab14ff29c422dbe7a ea74193fae6.pdf

[15] Mulyadi, S., Rahardjo, W., \& Basuki, A. M. H. (2016). The role of parent-child relationship, selfesteem, academic self-efficacy to academic stress. Procedia-Social and Behavioral Sciences, 217(2016): 603-608

[16] Naik, P., Harris, V. W., \& Forthun, L. F. (2013). Mindfulness: An introduction. Retrieved from https:// www.researchgate.net/publication/261528260_Mindful ness_An_Introduction

[17] Nuraini, T. N. (2020). Cerita lengkap asal mula munculnya virus corona di Indonesia. Retrieved from: https://www.merdeka.com/trending/cerita-lengkap-asalmula-munculnya-virus-corona-di-

indonesia.html?page $=3$
[18] Pajares, F. (1996). Self-efficacy beliefs in academic settings. Review of Educational Research, 66(4): 543-578.

[19] Prasetyo, A. Y. (2020). Memutus rantai penularan covid-19. Retrieved from: https://interaktif.kompas.id/ baca/memutus-covid-19/

[20] Rachman, C. (2020). Mahasiswa tuntut hak belajar saat pandemi. Retrieved from https://fixindonesia. pikiran-rakyat.com/muda/pr-36571773/mahasiswatuntut-hak-belajar-saat-pandemi 